\title{
Congress attacks contractor, accountants
}

\section{Washington}

Although supporters of the Superconducting Supercollider (SSC) insist that the massive particle accelerator is being built "on time and under budget", a congressional investigation revealed last week that the Texas project still has more than its share of financial and management problems.

Investigators have documented a power struggle between the managers of the SSC laboratory and the private building contractors that could put the project millions of dollars over its estimated cost of $\$ 8,255$ million and months behind its 1999 completion date. But the impact of the clash remains an open question because the Department of Energy (DOE), which oversees the project, has admitted that it has no effective accounting structure.

At a hearing last week before the oversight and investigations subcommittee of the House Science, Space and Technology Committee, the congressional General Accounting Office (GAO) testified that the SSC is reaching its challenging technical milestones without much trouble. But the same cannot be said of its 54mile elliptical tunnel and accompanying scientific buildings.

Early in the construction process, officials were forced to move the Magnet Development Laboratory after geologists discovered an aquifer directly under the original site. Racing to regain lost time, builders started construction before its design had been finished. When officials realized that the laboratory would be too small, they had to rebuild it partially and expand it.

A second snag arose from a new analysis of the underground site for the large experimental halls that will contain the SSC's largest detectors. Project managers decided that the rock on the other side of the ring was better suited for tunnelling. GAO testified that this could delay the project by 13 months and add $\$ 400$ million to the cost.

DOE officials justify the switch by saying that it would have taken even longer for geologists to decide how to keep the experimental halls on the west side of the ring, as originally planned. And although the start of construction will be delayed by the change, DOE thinks that it can get back on schedule by such approaches as designing the experimental halls while they are being built (despite the failure of that approach with the magnet laboratory) and building only one large experiment hall rather than the two now planned.

Strained relations between the laboratory and its construction contractors, Parsons Brinckerhoff-Morrison Knudsen (PB/MK), have further complicated matters. Some cost estimates have turned out to be too low after the contractor cut corners without authorization. In one case,
$\mathrm{PB} / \mathrm{MK}$ decided unilaterally to extend by 10 metres the spacing between some 150 equipment 'niches' in the tunnel. The change would have allowed it to build three fewer niches.

Other cost estimates have been found by the GAO to be too high after both parties included the same portion of the project in their own plans and budgets. Russ Wylie, the SSC's director of external affairs, blames the problem on an "ongoing difference of opinion between $\mathrm{PB} / \mathrm{MK}$ and the lab over the scope of the services". Several attempts to restrain the contractor over the past year were unsuccessful, but Wylie insists that the situation has changed.

A cost estimate on 1 September by SSC officials put the most optimistic forecast at $\$ 73$ million over the $\$ 1,500$ million "baseline" construction plan. A "pessimistic" forecast has the cost exceeding the baseline by as much as $\$ 383$ million.

Although the officials did not report these figures to DOE, some of the other problems were already becoming evident. Henson Moore, then DOE deputy secretary, warned in a letter dated 24 January to Roy Schwitters, the SSC director, that construction management appeared to have got out of hand and might call for legal action. "I have learned that the overrun problems are continuing and may even be getting worse," Moore wrote. He said that he was "extremely upset at this news" and demanded a plan to bring SSC construction back under control.

On 1 April, after negotiations with the contractor, SSC officials recalculated their costs. Instead of assured overruns, the new estimate gives a range of $\$ 300$ million, from a saving of $\$ 142$ million to an overrun of $\$ 160$ million. Critics quickly dubbed it the "April Fools' Day forecast" (noting that a yearly "escalation factor" had been arbitrarily set at 3.5 per cent less than previous estimates), but DOE officials explained that most of the savings came from removing parts of the project that the contractor had wrongly claimed as its own responsibility.

Although neither GAO nor the subcommittee's investigators has been able to refute DOE's estimates, each is convinced that the forecasts are unrealistic. Part of the problem, GAO testified, is that DOE's accounting methods make it nearly impossible to predict the impact of design changes and delays. DOE says that it has adopted better accounting and management procedures.

But getting to the bottom of the SSC's accounts has been complicated by what subcommittee members describe as a concerted campaign by DOE to avoid outside scrutiny. "Documents have been withheld, information shared only sparingly and there have even been attempts to pull strings to stop our oversight activities," said Representative Sherwood Boehlert (Republican, New York). "Never have so many done so much to avoid the scrutiny of so few."

Last year, the subcommittee threatened to issue a subpoena when it could not get the documents it wanted (see Nature 354, $259 ; 1991)$. The panel hopes that DOE will be more cooperative after being scolded in public.
Christopher Anderson

\section{Military stands firm on dissection}

\section{Washington}

Although many US universities now offer alternatives to animal dissection in medical training, military officials stuck by their guns in a congressional hearing last week and refused to offer exemptions to students who seek such alternatives.

Officers from the Uniformed Services University of the Health Sciences (USUHS) in Bethesda, Maryland, explained that their students agree upon admission to dissect animals as part of their training. University officials said that they do not believe that animal alternatives, such as computer simulations, are adequate substitutes for the use of animals by students.

Last year, Representative Ron Dellums (Democrat, California), chairman of the research and development subcommittee of the House Armed Services Committee which held last week's hearing, and ten other Members of Congress wrote USUHS asking the university to explore non-ani- mal alternatives and to allow students to be exempted on religious or ethical grounds. USUHS officials said no.

Elsewhere, the dissection issue has generally been handled on a case-by-case basis at US universities. The American Medical Association supports offering alternatives to students who choose not to participate in animal dissection. Several US universities, including the medical school at the University of Maryland, have eliminated animal laboratories from their curricula.

Military officials at the hearing also defended their use of animals in research against criticism from six animal-rights and animal-welfare organizations that offered examples of what they considered to be abusive and wasteful research. But Dellums is not convinced. He said that he might call another hearing, closed to the public, to review classified military research on animals.

Christopher Anderson 